\title{
Mekanisme Penanganan Kejahatan Insider Trading Pasar Modal Di Indonesia
}

\author{
Prawitra Thalib \\ Anwar Rachman dan Rekan, prawitra 36888@yahoo.com
}

\begin{abstract}
Insider trading is one of a crime that has a systemic impact and it's difficult to prove. An abstractness of its action makes it hard to prove. Also, the impact has tremendous effect to the stock exchange in the stock market, an unhealthy condition of the stock exchange is very dangerous because it can make disbelief from the stakeholders which automatically will effect on investment in some countries. Therefore, effective handling is needed to take action against insider trading.
\end{abstract}

Keywords : Insider Trading, Stakholder, Invesment

\begin{abstract}
Abstrak
Insider trading adalah salah satu kejahatan yang memiliki dampak sistemik yang pembuktiannya tergolong sulit dilakukan, keabstrakan dari tindakan nyata yang dilakukan oleh si pelaku itulah yang menjadikannya sulit untuk dibuktikan, tidak hanya itu dampak yang ditimbulkannya juga memiliki efek yang luar biasa terhadap transaksi pasar modal di bursa efek, kondisi pasar modal yang tidak sehat ini amatlah berbahaya karena dapat menimbulkan ketidak percayaan bagi stakeholder yang secara otomatis akan dapat mempengaruhi iklim investasi di suatu negara, untuk menjamin hal tersebut maka perlu dilakukan penanganan yang efektif dalam menindaklanjuti kejahatan insider trading tersebut.
\end{abstract}

Kata Kunci: Insider Trading, Pasar Modal, Stakeholder

\section{Pendahuluan}

Insider trading adalah suatu kejahatan

di Pasar Modal yang sangat sulit untuk dibuktikan, bahkan di negara yang sudah maju sekalipun seperti Amerika Serikat. Tidaklah mudah untuk membawa pelaku kejahatan ini ke dalam peradilan pidana. Insider trading ini sangatlah berbahaya karena dampaknya yang sangat luar biasa dalam suatu pasar modal, karena kejahatan ini dapat menyebabkan perkembangan pasar modal menjadi terhambat dan juga dapat secara tidak langsung mengakibatkan bursa efek manjadi sepi dan tidak bergairah karena kecurangan-kecurangan oknum yang bertanggung jawab dalam insider trading tersebut. Oleh karena itu secara tidak langsung makalah ini juga akan membahas sejauh mana kasus insider trading berakibat pada pengembangan pasar modal Indonesia. 
Hal ini terkait dengan sulitnya pembuktian atas praktek kejahatan tersebut. Fenomena ini menarik bagi penulis untuk menelitinya. Setelah melalui beberapa kajian secara mendalam dengan dukungan data dan informasi baik dari literatur, fakta nyata maupun beberapa riset skala kecil yang telah penulis lakukan, penulis menemukan beberapa permasalahan yang terkait dengan penanganan insider trading di Indonesia yaitu kendala dalam pembuktian insider trading, dampak insider trading terhadap perkembangan pasar modal Indonesia, perlindungan investor terhadap insider trading dan penyelesaian insider trading di Pasar Modal Indonesia. ${ }^{1}$ hal inilah yang mendasari pentingnya mengkaji cara penanganan kejahatan insider trading yang terdapat dalam pasar modal di Indonesia.

\section{Pembahasan}

Fenomena Pasar Modal Salah satu cara untuk pengembangan ekonomi di Indonesia yaitu melalui pasar modal yang merupakan sumber pembiayaan jangka menengah dan jangka panjang dalam usaha memobilisasi dana masyarakat guna pengembangan dunia usaha. Sejak diaktifkannya pasar modal di Indonesia pada tahun 1977, Pemerintah telah melakukan berbagai upaya untuk memajukan pasar modal. Melalui Bapepam sebagai institusi Pemerintah yang memiliki kewenangan dalam membuat kebijakan sesuai dengan Pasal 4 Undang-undang No. 8 tahun 1995 tentang Pasar Modal, diharapkan mampu mewujudkan pasar modal yang lebih menjanjikan untuk kemajuan dunia usaha.

${ }^{1}$ Bapepam \& CMS, Cetak Biru Pasar Modal Indonesia, Jakarta, 1996, h. 12
Perkembangan yang cukup menggembirakan dalam beberapa tahun yang lalu menunjukkan pasar modal merupakan salah satu bidang jasa keuangan di Indonesia yang cukup diminati. Hal ini tampak dari besarnya dukungan untuk pengembangan pasar modal baik dari pelaku pasar modal maupun Pemerintah. Melalui potensi para pemodal dewasa ini baik perorangan maupun institusional, lebihlebih lagi dengan dibukanya kesempatan bagi investor asing untuk berpartisipasi dalam pasar modal di Indonesia.

Diharapkan prospek pasar modal ke depan semakin menjanjikan. Investor asing memiliki banyak pilihan, disamping mencari saham di bursa terkenal di Asia seperti Tokyo Stock Exchange di Jepang, Taiwan Stock Exchange di Taiwan, dan Seoul Stock Exchange di Korea Selatan, juga dapat dicari di bursa kawasan Asia Tenggara seperti Bursa Malaysia di Malaysia, The Stock Exchange of Thailand di Thailand, Singapore Exchange Ltd. di Singapore, dan tentunya Bursa Efek Jakarta di Indonesia. ${ }^{2}$

Perkembangan pasar modal ditentukan pula oleh berbagai kinerja organisasi, yaitu Bapepam, Bursa Efek, Lembaga Kliring dan Penjaminan, Lembaga Penyimpanan dan Penyelesaian, Lembaga dan Profesi Penunjang Pasar Modal. Dari struktur organisasi pasar modal, fungsi Bapepam merupakan komponen yang memegang peranan penting terhadap kemajuan pasar

${ }^{2}$ I Nyoman Tjager, "Pasar Modal Indonesia" Kertas Kerja Disampaikan pada Pelatihan Teknis Yudisial Pengadilan Niaga Para Calon Hakim Pengadilan Niaga di Malang, tanggal 13 September 1998. 
modal Indonesia. Hal ini sesuai dengan yang diamanatkan Pasal 3 Undang-Undang Pasar Modal yaitu pembinaan, pengaturan dan pengawasan kegiatan Pasar Modal dilakukan oleh Bapepam.

Kunci keberhasilan tugas Bapepam tersebut antara lain sejauh mana produk Bapepam (pembinaan, pengaturan dan pengawasan) mampu memuaskan para konsumennya, baik internal yaitu antar unit kerja di lingkungan Bapepam maupun eksternal yaitu pelaku-pelaku Pasar Modal. Dalam upaya memuaskan para stakeholdernya, maka penting dilakukan penerapan sistem kualitas oleh Bapepam, yang meliputi perencanaan kualitas, pengendalian kualitas dan peningkatan kualitas. Urgensi Bapepam Sebagai regulator, Bapepam perlu mengetahui apakah peraturanperaturan yang diterapkan di Pasar Modal sudah berlandaskan kualitas atau belum, karena apabila belum maka peluang terjadinya penyimpangan dan pelanggaran hukum semakin besar. Dengan demikian diperlukan suatu instrumen, yaitu Quality Legal Audit yang berbeda dengan Hak Uji Material di Mahkamah Konstitusi. Perbedaannya adalah Quality Legal Audit bersifat interdisipliner, sedangkan Hak Uji Materiil bersifat monodisipliner. ${ }^{3}$

Tentunya pertumbuhan Pasar Modal perlu didukung oleh sistem dan mekanisme yang berpijak pada aturan main yang jelas. Rule of Game harus direfleksikan ke dalam bentuk ketentuan hukum yang mengatur gerak dan langkah pelaku

${ }^{3}$ M. Daud Silalahi, Quality Legal Audit, mimeograf, Law and Environmental Consultant, Lawencon, Bandung, 1999, h. 50 dalam menjalankan aktivitas Pasar Modal. Setiap pelaku pasar, atau mereka yang menundukkan diri kepada ketentuan hukum yang berlaku di Pasar Modal, diperkenankan menciptakan atau melakukan berbagai metode dan strategi investasi, bebas berkreasi serta menjalankan berbagai jenis usaha, seperti tertuang dalam Peraturan Pemerintah Nomor 45 Tahun 1995 tentang Penyelenggaraan Kegiatan Di Bidang Pasar Modal. Kebebasan dalam menjalankan aktivitas di Pasar Modal tentunya perlu bahkan harus dibatasi oleh rambu-rambu hukum dan tata cara yang ditentukan oleh perangkat perundangundangan serta ketentuan pelaksanaan lainnya.

Bila terdapat pelanggaran, konsekuensinya akan berhadapan dengan sanksi hukum sesuai dengan jenis dan kualitas pelanggaran. Upaya untuk melakukan penegakan hukum harus berlangsung secara konsisten dengan tetap memperhatikan kepentingan perkembangan Pasar Modal itu sendiri. Badan Pengawas Pasar Modal (Bapepam) berdasarkan UU Nomor 8 Tahun 1995 tentang Pasar Modal memiliki kewenangan yang sangat besar untuk melakukan pembinaan, pengaturan dan pengawasan kepada industri pasar modal diharapkan mampu menjalankan fungsinya sesuai dengan yang diamanatkan UU tersebut. ${ }^{4}$

Disamping itu, untuk menjalankan pengawasan secara represif, Bapepam diberi kewenangan melakukan pemeriksaan, penyelidikan dan penyidikan seperti diatur

${ }^{4}$ Marzuki Usman dkk., ABC Pasar Modal Indonesia, Institut Bisnis Indonesia, Jakarta, 1994, h. 26 
dalam Peraturan Pemerintah Nomor 46 Tahun 1995 tentang tata cara pemeriksaan di Pasar Modal. Dalam rangka itulah maka sesuai dengan amanah yang digariskan dalam Undang-Undang Pasar Modal, bahwa dalam rangka menyempurnakan pengaturan pasar modal telah dikeluarkan serangkaian peraturan yang memberikan kepastian dan jaminan hukum bagi para pelaku pasar modal.

Pada saat ini upaya berkesinambungan dilakukan oleh Pemerintah dan masyarakat agar hukum dapat mengayomi dan menjadi landasan bagi kegiatan masyarakat dan pembangunan. Adanya kepastian hukum merupakan wahana untuk timbulnya kepercayaan kepada pasar. Salah satu syarat agar pasar modal mampu mengembangkan perekonomian Indonesia adalah kejahatan di pasar modal khususnya insider trading harus dapat ditemukan dan diselesaikan melalui hukum yang berlaku baik itu kebiasaan maupun karena telah diatur dalam aturan di pasar modal. Memang harus diakui bahwa kejahatan ini tidak mudah untuk ditemukan apalagi diselesaikan, hal ini karena tidak didukung oleh sistem hukum yang ada saat ini di Indonesia. Oleh karena itu perlu kiranya ke depan dipertimbangkan suatu harmonisasi ketentuan hukum yang ada dengan perkembangan akan kebutuhan hukum itu sendiri. ${ }^{5}$

Hal ini dimungkinkan mengingat bahwa sistem hukum terus berubah, namun bagian-bagian sistem itu berubah dalam kecepatan yang berbeda, dan setiap bagian

${ }^{5}$ Lawrence M. Friedman, American Law An Introduction (Second Edition), Tata Nusa, Jakarta, 2001,h. 7 berubah tidak secepat bagian tertentu lainnya. Inilah struktur sistem hukum, kerangka atau rangkanya, bagian yang tetap bertahan, bagian yang memberi semacam bentuk dan batasan terhadap keseluruhan. Persoalan tentang perubahan hukum dan perubahan masyarakat pada pokoknya terdiri dari dua butir terpenting tentang hukum dan perubahan masyarakat itu, yaitu :

1. Sejauh mana perubahan masyarakat harus mendapatkan penyesuaian oleh hukum. Dengan lain perkataan, bagaimana hukum menyesuaikan diri dengan perubahan masyarakat.

2. Sejauh mana hukum berperan untuk menggerakkan masyarakat menuju suatu perubahan yang terencana.

Sebagaimana diketahui bahwa sistem hukum Indonesia saat ini masih menganut sistem hukum Eropa Kontinental yang diadopsi dari Belanda, yaitu berdasarkan asas konkordansi, sedangkan Pasar Modal menganut unsur-unsur hukum dalam sistem hukum Anglo Saxon yang dikembangkan di Amerika. Sistem Common Law lebih mengacu kepada hukum kebiasaan (Customary Law) yang cenderung tidak tertulis.

Sumber hukum utama dalam sistem Civil Law adalah perundang-undangan, walaupun terdapat sumber hukum lain seperti kebiasaan, yurisprudensi dan doktrin. Berbeda dengan sistem Common Law, Mengingat masalah-masalah hukum

${ }^{6}$ Achmad Ali, Menguak Tabir Hukum (Suatu Kajian Filosofis dan Sosiologis), Gunung Agung, Jakarta, 2002, h. 191. 
diselesaikan kasus perkasus yang hasilnya tercermin dalam putusanputusan hakim (yurisprudensi), maka sumber hukum utama adalah yurisprudensi (judge made law). Dalam sistem Civil Law, karena terbiasa mengacu kepada peraturan perundangundangan yang masih memerlukan penafsiran, antara lain penafsiran gramatikal, historis, authentic, dan kontruksi hukum, ahli hukum dari Negara- Negara Eropa Continental lebih kuat dalam penafsiran. ${ }^{7}$

Dari perbedaan kedua sistem hukum antara Common Law dan Continental Law tersebut, mengakomodasikan kedua sistem ini akan dikaji dari segi aspek hukum untuk membuat suatu format bagaimana solusi untuk menyelesaikan kejahatan insider trading. Aspek hukum Pasar Modal tersebut sering menjadi sorotan dan merupakan obyek diskusi yang menarik karena menyangkut teori-teori hukum tentang perdagangan orang dalam (insider trading). Teori hukum yang berhubungan dengan praktik perdagangan orang dalam tersebut merupakan teori-teori hukum yang menjadi landasan tentang pengaturan aspek yang berhubungan dengan transaksi yang dilakukan oleh orang dalam (insider). ${ }^{8}$

Sebagaimana diketahui bahwa insider trading disamping dituntut secara perdata mengenai kepatutan atau kepantasan juga dapat dituntut secara pidana sebagaimana disebutkan dalam Undang-undang Nomor 8 Tahun 1995 tentang Pasar Modal, namun

\footnotetext{
7 Jusuf Anwar, Kajian Tentang Kepastian Hukum Kinerja Lembaga Pasar Modal di Indonesia Dalam Upaya Menunjang Pembangunan Nasional, Univ. Padjadjaran, Bandung, 2001, h. 16

${ }^{8}$ Ibid.
}

sebagaimana kasus sejenis yang muncul diberbagai negara yang penyelesaian kasus tersebut cenderung kearah ganti rugi atau denda oleh lembaga regulator Pasar Modalnya.

Meskipun disadari akibat dari perbuatan tersebut yaitu insider trading sangat besar pengaruhnya baik kepada investor maupun terhadap pengembangan Pasar Modal secara keseluruhan, maka sanksi atas perbuatan melawan hukum tersebut tidak cukup dengan mengganti kerugian saja jika diperlukan diberikan efek jera bagi si pelaku misalnya sanksi pidana sebagaimana disebutkan dalam Undangundang Nomor 8 Tahun 1995 tentang Pasar Modal dan Undang-undang Nomor 5 Tahun 1999 tentang Larangan Praktik Monopoli dan Persaingan Usaha Tidak Sehat.

Namun perlu dilakukan telaah hukum secara mendalam akan kejahatan insider trading agar hukuman yang diterima tepat sasaran dan memiliki efek jera, terlepas sanksi tersebut berupa sanksi perdata atau pidana. Sistem Pengawasan di Pasar Modal Dari studi kasus pelanggaran hukum pasar modal khususnya insider trading, tergambar bahwa demikian luas dan rumitnya tindak pelanggaran di pasar modal. Hal ini harusnya dapat diakomodir dalam pengembangan hukum Indonesia. Oleh karena itu dalam rangka penegakan hukum serta dalam konsep pembentukan hukum nasional, nampaknya hukum tidak hanya diartikan secara terbatas dan hanya terpaku kepada hukum tertulis saja. Lebih lebih untuk mengantisipasi pelanggaran hukum di pasar modal, karena memang pasar modal 
Indonesia diadopsi dan lebih condong ke Amerika Serikat yang menganut sistem hukum Anglo Saxon dan berbeda dengan sistem hukum yang berlaku di Indonesia, hal ini memang sudah lama diperdebatkan.

Apabila hanya penerapan hukum tertulis saja yang berlaku di Indonesia, maka dikhawatirkan penegakan hukum atas kejahatan dan pelanggaran hukum di bidang pasar modal akan sulit dilakukan, sebagai contoh sulitnya penyelesaian kasus insider trading di pasar modal Indonesia karena terbatasnya masalah pembuktian yang dianut dalam hukum tertulis Indonesia. Jika Indonesia terlalu teguh berpegang pada hukum tertulis, maka penegakan hukum pasar modal akan sulit, berdasarkan pengalaman, dalam kodefikasi pun sering terdapat kekosongan hukum (terdapat halhal yang belum diatur) dan di lain pihak semakin jauhnya pelaksanaan hukum dari keadilan disebabkan terlalu tegarnya memegang undang- undang dan kodefikasi. Oleh karena itu tepat kiranya jika dalam penegakan hukum pasar modal, regulator dapat menyesuaikannya dengan keadaan dan kondisi yang berkembang.

Jika dikaitkan dengan aliran pemikiran hukum, hal ini sejalan dengan pemikiran hukum dari aliran rechtsvinding yang merupakan aliran tengah diantara aliran legisme dan freie rechtsbewegung. Bahwa menurut aliran rechtsvinding, benar bahwa hakim terikat pada undangundang, akan tetapi tidaklah seketat seperti menurut pandangan aliran legisme yang menganggab semua hukum terdapat dalam undang-undang, karena hakim juga memiliki kebebasan. Namun kebebasan hakim tidak seperti anggapan aliran freie rechtsbewegung, sehingga di dalam melakukan tugasnya hakim mempunyai apa yang disebut "kebebasan yang terikat" (gebonded vrijheid) atau "keterikatan yang bebas" (vrije gebondenheid). ${ }^{9}$

Oleh sebab itu maka tugas hakim disebutkan sebagai upaya melakukan rechtsvinding yang Pasar modal artinya adalah menselaraskan undang-undang pada tuntutan zaman dapat diklasifikasikan sebagai bidang hukum yang netral. Dalam pembentukan hukum pasar modal, apabila melihat Undang-undang Pasar Modal, pembentukannya mendapat pengaruh dari sistem hukum Anglo Saxon. Ini terbukti misalnya terdapat lembaga Wali Amanat dalam industri pasar modal. Oleh karena itu, pasar modal sebagai bidang hukum yang netral, maka tidak menutup kemungkinan mendapat pengaruh dari berbagai sistem hukum. Dalam teori pembentukan hukum, hakim dapat dianggap sebagai satu faktor pembentuk hukum.

Hakim wajib menemukan hukum atas suatu perkara yang ia tangani. Asas ini dianut dalam pasal $22 \mathrm{AB}$ (Algemene Befalingeen) yang walaupun merupakan produk hukum zaman kolonial tapi asas ini masih berlaku dalam tatanan hukum di tanah air hingga sampai saat ini. Penafsiran dan penemuan hukum juga menjadi faktor bagi pengembangan hukum pasar modal, dalam hal ini hakim sebagai salah satu penegak hukum harus dapat menemukan dan menerapkan hukum yang berlaku bagi

\footnotetext{
9 Ibid.
} 
penyelesaian kasus pelanggaran hukum pasar modal yang dihadapinya, hal ini sesuai dengan ketentuan Pasal 14 ayat (1) UU No. 14/ 1970 tentang Ketentuanketentuan Pokok Kekuasaan Kehakiman, yang telah diubah dengan Undang-undang No.35 Tahun 1999 tentang Perubahan atas Undang-undang No.14 Tahun 1970 tentang Ketentuanketentuan Pokok Kekuasaan Kehakiman, terakhir dengan Undangundang No.4 Tahun 2004 tentang Kekuasaan Kehakiman Pasal 28 ayat (1) Hakum wajib menggali, mengikuti dan memahami dan rasa keadilan yang hidup dalam masyarakat Hakim dalam melaksanakan fungsi dan kewenangan kehakiman diberikan otonomi kebebasan.

Otonomi kebebasan itu mencakup menafsirkan peraturan perundangundangan, mencari dan menemukan asasasas dan dasar-dasar hukum, mencipta hukum baru apabila menghadapi kekosongan peraturan perundang-undangan, dibenarkan pula melakukan contra legem apabila ketentuan peraturan perundangundangan bertentangan dengan kepentingan umum, dan memiliki otonomi yang bebas untuk mengikuti yurisprudensi. Dengan kewenangan yang dimiliki hakim tersebut, penemuan hukum yang dilakukan tidak sekedar menginterpretasi undang-undang atau hanya melaksanakan undang- undang saja, tetapi juga penemuan hukum karena hakim bukan hanya sebagai corong undangundang (la bouche du droit). Melalui interpretasi yang baik, hukum akan tetap hidup dari masa ke masa dan memberikan keadilan bagi mereka yang mendambakan.
Dengan demikian proses pengadilan bukanlah suatu silogisme. Undang-undang merupakan premis mayor, peristiwa kongkrit adalah premis minor, sedangkan putusan hakim adalah konklusi atau simpulannya. Karena itu relevan jika penerapan hukum tidak semata-mata melihat kepada hukum tertulis. Apabila Hakim tidak menemukan hukum tertulis maka wajib menggali hukum tidak tertulis untuk memutus berdasarkan hukum sebagai seorang yang bijaksana dan bertanggung jawab. Untuk mengantisipasi pelanggaran di pasar modal yang masuk dalam kategori praktek curang (unfair trading) dan kejahatan pasar (market crime) diperlukan pengetahuan tentang jenis- jenis pelanggaran yang masuk dalam kelompok tersebut. Disamping upaya penegakan hukum pasar modal, perlu pula kiranya untuk mendapat perhatian upaya-upaya preventif untuk menganulir kemungkinankemungkinan yang mengancam industri pasar modal di tanah air.

Diantara upaya-upaya preventif tersebut adalah saksi pelapor atau sumber informasi wajib untuk dilindungi. Penegakan Hukum Sebagai Upaya Penyelesaian Masalah Insider Trading Hampir di semua pasar modal di dunia memiliki peraturan yang melarang insider trading. Sekalipun demikian masih saja terdapat perdebatan mengenai perlu tidaknya melarang kegiatan insider trading. Karena dalam prakteknya, hampir tiada batas yang jelas antara salah dan benar dalam insider trading. Kalangan pakar ekonomi finansial dan ahli hukumpun belum ada kesepakatan dalam banyak aspek tentang insider trading. 
Menurut seorang pakar di bidang keuangan melihat insider trading sebagai masalah jika terdapat unsur penipuan (fraud atau deceit). Misalnya pendapat Michael Rozeff, Profesor dari University of Iowa yang banyak menulis tentang insider trading, menyimpulkan bahwa insider trading merupakan topik yang masih kontroversial dan belum ada kesepakatan tentang ini. Menurutnya, sebagian besar investor menerima insider trading sebagai suatu kenyataan. insider trading akan menarik perhatian masyarakat setelah melewati berita yang spektakuler tentang kasus insider trading di media massa. ${ }^{10}$

Menarik untuk disimak adalah dua pendapat yang saling bertentangan. Pendapat pertama diungkap oleh H. Manne yang memaparkan hal tentang insider trading sebagai berikut: "Insider trading provides an incentive for entrepreneurial activity, and that it enhances market efficiency through the faster dissemination of information". ${ }^{11}$

Artinya bahwa insider trading memberikan satu insentif bagi kegiatan kewirausahaan, dan dapat meningkatkan efisiensi pasar melalui informasi yang cepat tersebar. Pendapat lainnya diungkap oleh U Bhattacharya dan H Daouk sebagai berikut:

"Recently, empirical studies have also found that the proper enforcement of insider trading laws reduces the cost of equity capital by about $5 \%$, which

\footnotetext{
10 Yudha Bhakti Ardhiwisastra, Penafsiran dan Konstruksi Hukum, Alumni, Bandung 2000, h. 51.

11 Ibid., h.60.
}

suggest that any advantage from a market efficiency perspective is outweighed by the loss of investor confidence caused by insider trading"

Artinya bahwa, berdasarkan studi empiris terkini didapat bahwa penegakan hukum terkait kasus insider trading akan mengurangi biaya modal kira-kira $5 \%$, keuntungan lain dari tindakan tersebut adalah efisiensi pasar tercapai sekaligus tingkat kepercayaan investor akan meningkat. Pendapat kedua ini banyak dukungan karena pesan yang begitu kuat akan perlindungan bagi investor dimana terdapat tiga hal penting yang akan dicapai jika penegakan hukum terhadap kasus insider trading dilaksanakan, yaitu: ${ }^{12}$

1. regulasi yang efektif dibidang hukum khususnya penegakan hukum secara umum akan menghasilkan pengembangan pasar modal ke arah yang lebih baik sekaligus perlindungan bagi investor;

2. regulasi yang efektif akan membentuk siklus keterkaitan positif antara investor dan perusahaan publik di mana dengan tingkat risiko yang rendah akan dicapai biaya operasional yang rendah pada akhirnya akan menarik perusahaan- perusahaan untuk menjadi perusahaan publik yang terdaftar di pasar modal;

3. para regulator dan badan yang menangani penegakan hukum di pasar modal wajib mampu untuk mendeteksi dan mencegah tindakan-

\footnotetext{
${ }^{12}$ Soedjono Dirdjosisworo, Pengantar Ilmu Hukum,
} RajaGrafindo Persada, Jakarta, 2000, h. 161. 
tindakan yang dapat merugikan investor.

Jika investor kehilangan kepercayaannya maka pasar modal akan masuk pada siklus negatif di mana nilai saham akan jatuh, perusahaan-perusahan publik yang masuk dalam kategori baik akan keluar dari pasar modal pada akhirnya aktivitas pasar modal secara keseluruhan akan terhenti. Tujuan utama dari pelaku insider trading adalah untuk memperoleh keuntungan melalui pemanfaatan informasi yang belum ter-publish kepada publik, sehingga pelakupelaku dapat dikenakan sanksi berupa ganti rugi, memang dalam hukum pidana dapat terlaksana "alat bukti yang dengan alat bukti sebagaimana disebut dalam Pasal 184 yang berbunyi: sah meliputi keterangan saksi, keterangan ahli, surat, petunjuk dan keterangan tersangka".

Hal ini amatlah sulit untuk dibuktikan selain itu alat bukti sebagaimana disebut dalam Pasal 184 ini tidak cukup untuk memenuhi pembuktian insider trading. Menurut undang-undang, ada lima macam alat pembuktian yang sah yaitu; suratsurat, kesaksian, persangkaan, pengakuan dan sumpah Jika ditelaah, alat bukti yang dimaksud dalam pasal tersebut maka insider trading tidak dapat dibuktikan karena bukti transaksi yang dilakukan di bursa merupakan hasil elektronik yaitu berupa print out dan bukan termasuk kategori surat sebagaimana disebutkan dalam undangundang. (sekalipun dengan adanya UndangUndang tentang transaksi elektronik telah disahkan tidak menutup kemungkinan bahwa pembuktian insider trading dalam hal secara tertulis sulit untuk dibuktikan) Oleh karena pelakunya melakukan insider trading untuk memperoleh keuntungan berupa uang, maka dapat dilakukan perubahan konsep pidana dari ultimum remedium ke primum remidium, yaitu diartikan sebagai Prinsip Ultimum Remedium dalam hal adanya sanksi administratif dan sanksi pidana, sanksi pidana tersebut baru akan digunakan efektif, jika sanksi administratif sudah dilaksanakan secara penuh.

\section{Penutup}

Para pelaku insider trading lebih efektif diarahkan pada perbuatan melawan hukum dan sanksi yang dikenakan berupa ganti rugi atau denda atau Alternative Dispute Resolution (ADR) dimana dijatuhkannya sanksi pidana adalah upaya akhir. Besarnya ganti rugi atau denda tersebut disesuaikan dengan tingkat kerugian akibat dari pelanggaran tersebut serta diupayakan mampu menimbulkan efek jera. Untuk menyelesaikan permasalahan di atas. Undang-undang Nomor 8 tahun 1995 tentang Pasar Modal perlu diamandemen yaitu memuat pembentukan Komisi Penyelesaian Kasus Pasar Modal. Komisi ini bertugas untuk menyelesaikan kasuskasus yang ada di pasar modal terutama insider trading. Keputusan Komisi adalah merupakan putusan final yang diberi kewenangan sebagai quasi eksekutif, quasi legislatif dan quasi yudisial. sehingga dalam perkembangan pasar modal kedepan kasus kejahatan insider trading tidaklah lagi menjadi momok yang sulit untuk dilakukan pembuktiannya sekalgus juga harus menjadi 
suatu kejahatan yang sulit untuk dilakukan karena disamping banyaknya pengawasan dari para pihak, penanganan terhadap kasus tersebut haruslah efektif, keras dan tegas, yang secara tidak langsung akan menjadikan transaksi pasar modal menjadi lebih sehat dan efisien.

\section{Daftar Bacaan}

Achmad Ali, Menguak Tabir Hukum (Suatu Kajian Filosofis dan Sosiologis), Gunung Agung, Jakarta, 2002.

Bapepam \& CMS, Cetak Biru Pasar Modal Indonesia, Jakarta, 1996.

Jusuf Anwar, Kajian Tentang Kepastian Hukum Kinerja Lembaga Pasar Modal di Indonesia Dalam Upaya Menunjang Pembangunan Nasional, Univ. Padjadjaran, Bandung, 2001.
M. Daud Silalahi, Quality Legal Audit, mimeograf, Law and Environmental Consultant, Lawencon, Bandung, 1999.

Marzuki Usman et al., ABC Pasar Modal Indonesia, Institut Bisnis Indonesia, Jakarta, 1994.

Lawrence M. Friedman, American Law An Introduction (Second Edition), PT Tata Nusa, Jakarta, 2001.

Soedjono Dirdjosisworo, Pengantar Ilmu Hukum, RajaGrafindo Persada, Jakarta, 2000.

Yudha Bhakti Ardhiwisastra, Penafsiran dan Konstruksi Hukum, Alumni, Bandung 2000. 